\title{
Combining Ability and Heterosis for Root Structure and Graft-Related Traits of Interspecific Cucurbita Rootstocks
}

Onur Karaağaç ( $\sim$ onur.karaagac@tarimorman.gov.tr)

Seed Certification and Variety Test Station, Ministry of Agriculture and Forestry https://orcid.org/0000-0002-8794-2556

\section{Research Article}

Keywords: Rootstock, C. maxima $\times$ C, moschata, Breeding, Combining ability, Root architecture

Posted Date: June 1st, 2021

DOI: https://doi.org/10.21203/rs.3.rs-531223/v1

License: (1) This work is licensed under a Creative Commons Attribution 4.0 International License. Read Full License

Version of Record: A version of this preprint was published at Euphytica on July 22nd, 2021. See the published version at https://doi.org/10.1007/s10681-02102884-y. 


\section{Abstract}

Interspecific hybrid Cucurbita rootstocks (Cucurbita maxima $\times$ Cucurbita moschata) are the most widely used rootstocks for Cucurbitaceous vegetables in the world. In recent years, scientists have focused on understanding and exploiting root architectures as new opportunities for crop improvement. Selection of parents and hybrids based on combining ability test is an effective approach in interspecific hybrid variety breeding. However, very little information is available on the combining ability tests for the rooting and graft-related traits in these rootstocks. Ondokuz Mayis University and Black Sea Agricultural Research Institute are conducting a program to breed Cucurbita rootstocks of Turkey for fifteen years. In this study, seven $C$. maxima (BC ${ }_{5} F_{1}$ generation) lines as female parents and three $C$. moschata $\left(S_{6}\right.$ generation) lines as male parents were used to obtain 21 crosses. Interspecific hybrids and their parent rootstocks grafted onto watermelon were analyzed in terms of general combining ability (GCA), specific combining ability (SCA), heritability, and heterosis for roots and graft-related traits including root volume $\left(\mathrm{cm}^{3}\right)$, root length $(\mathrm{m})$, root dry weight $(\mathrm{g})$, hairy root rate $(\%)$, average root diameter $(\mathrm{mm})$, shoot dry weight (g), graft success rate (\%), and hypocotyl thickness ratio (\%) by using line $\times$ tester mating design. The quotient of GCA/SCA effects for all root and hypocotyl traits were higher than 1 , suggesting the preponderance of additive over non-additive gene action in the expression of these traits, whereas graft success was controlled by additive and non-additive gene effects. It was determined that average root diameter had high heritability (63.85\%) and the other traits had intermediate heritability ranging from $40.59 \%$ to $58.98 \%$. Combining ability analyses indicated that FTS5, GH12, and GRD17 lines were promising parents with greater general combining ability. Three crosses, GRD17 × FTS5, B12 × FTS5, and BH5 × CHI2 showed superior mid-parent heterosis and significant SCA for most characters. Present findings will provide significant contributions in understanding of inheritance and then achieving desirable improved rootstocks in $C$. maxima $\times$ C. moschata.

\section{Introduction}

The use of rootstock has become a common technique for Cucurbits in many parts of the vegetable production areas in the world, due to its efficacy against stresses. Grafting usually increases yield by invigorating scions and extending the harvest periods (Bie et al. 2017). High-capacity root systems of rootstocks improve water and nutrient uptake of grafted plants (Devi et al. 2020). Watermelon is the first grafted vegetable species and grafting is used as an effective alternative of crop rotation (Hassell et al. 2008). Cucurbita spp., Lagenaria siceraria, Benincasa hispida, Sicyos angulatus, Cucumis spp. and Citrullus spp. rootstocks have been used for Cucurbits grafting with varying degrees of success (Picó et al. 2017). Commercial Cucurbits are most commonly grafted onto interspecific Cucurbita hybrid (C. maxima $\times$ C. moschata) rootstocks (Edelstein et al. 2017). These interspecific hybrids have become a widely accepted paradigm for vigorous rootstocks that improve yield and biotic resistance of Cucurbits (Thompson et al. 2017). C. maxima $\times$ C. moschata crosses generally give rather poor fruit set and seed yield, and usually produce a sterile hybrid plant (Karaağaç and Balkaya 2013). Early studies to overcome this problem were initiated in the USA and Japan (Whitaker 1933; Hayase 1950). The first C. maxima $\times$ C. moschata interspecific rootstock was developed by Japanese breeders (Kanda 1984). Selections for cross compatibility and to increase seed yield have led to a decrease in genetic variation. Furthermore, these hybrids are very similar to each other as improved lines are used as parents of many hybrids (Kong et al. 2014; Edelstein et al. 2017). Therefore, it is necessary to develop unique interspecific hybrid rootstocks with the use different genetic resources. For this purpose, it has been reported that interspecific inbred winter squash lines could be used as bridge lines to transfer good traits between C. maxima and C. moschata in recent years (Korakot et al. 2010; Zhang et al. 2012; Ara et al. 2013).

Although present selection efforts mostly focus on above-ground parts, roots still constitute an underutilized source of plant breeding (Wachsman et al. 2015). Determination of phenotypic variability in root traits is still the most difficult issue in rootstock breeding programs. Root system architecture (RSA), the threedimensional form of a root, is used to describe distinct aspects of the configuration of roots (Ye et al. 2018). With the RSA analysis, large-scale screening of germplasm and selected lines would be very useful for rootstock breeding programs (Sheshshayee et al. 2011).

Combining ability is an important tool used by plant breeders to accumulate beneficial genes and reveal heterosis in hybrid variety breeding (Dehdar et al. 2020). General combining ability is ascribed to additive type of gene effects, while specific combining ability is attributed to non-additive type of gene actions (Kanagarasu et al. 2010). The line $\times$ tester design is one of the effective method available to determine the combining ability effects and helps in selecting lines and crosses in pedigree selection (Fellahi et al. 2013). Involvement of both additive and dominance gene actions was reported for genetic control in winter squashes (Korzeniewska and Niemirowicz-Szczytt 1993; Anido et al. 2004; Tamilselvi et al. 2015; Darrudi et al. 2018). However, in these studies, winter squashes were not evaluated in terms of rootstock characteristics. In addition, some studies revealed root characteristics of Cucurbita rootstocks in recent years, but gen action were not examined (Edelstein et al. 2017; Bertucci et al. 2018; Karaağaç 2020). Until now, there has been no information on the combining ability and heterosis for interspecific Cucurbita rootstocks (C. maxima $\times$ C. moschata) and their parents. The objectives of this study are to determine the combining ability, to assess the gene actions and to exhibit heritability and heterosis for root structures and graft-related traits in a line $\times$ tester analysis of interspecific Cucurbita rootstocks (C. maxima $\times$ C. moschata).

\section{Materials And Methods}

Genetic materials

Winter squash parent lines were from the Cucurbita rootstock breeding program in Black Sea Agricultural Research Institute (BSARI), Turkey. Selection breeding was applied to increase the interspecific cross ability and hybrid seed yield of female parent $C$. maxima lines (Karaağaç, 2013). These lines backcrossed with bridge lines close to $C$. moschata and selfed five times with the use of modified procedure of Korakot et al. (2010) for five years between 2008 and 2014 (Fig. 1). C. maxima $\left(\mathrm{BC}_{5} \mathrm{~F}_{1}\right.$ generation) and C. moschata ( $\mathrm{S}_{6}$ generation) lines were developed by the pedigree selection method with evaluation of F. oxysporum f. sp. niveum resistance, plant vigor, female flower productivity, pollen quality, and hybrid seed yield. The pedigrees of the parental rootstock are described in Table 1. Inbred lines of seven female parents ( $C$. maxima) and three male parents ( . moschata) were used to obtain 21 interspecific hybrids according to the line $\times$ tester design. 
Table 1

Description of improved Cucurbita rootstock parents

\begin{tabular}{|c|c|c|c|c|c|}
\hline Parents & & Fruit Group & Pedigree & Superior properties ${ }^{a}$ & Country of origin \\
\hline \multicolumn{6}{|c|}{ Female C. maxima } \\
\hline & B12 & Buttercup & B12/AM2*5/B12 & BT, SY, FFP & Turkey \\
\hline & BH5 & Hubbard & K11/B8*5/K11 & $\mathrm{BT}, \mathrm{FFP}, \mathrm{FR}$ & Mexico \\
\hline & $\mathrm{GH} 12$ & Hubbard & K44/B8*5/K44 & BT, FFP, PV & Peru \\
\hline & GLD9 & Delicious & K19/PE75/K19 & SY, FR, PV & Uruguay \\
\hline & GRD17 & Delicious & K36/ PE7 ${ }^{\star} 5 / \mathrm{K} 36$ & SY, FR, PV & Argentina \\
\hline & JA2 & Jarrahdale & $\mathrm{K} 1 / \mathrm{CHI} 8^{*} 5 / \mathrm{K} 1$ & SY, FFP & Turkey \\
\hline & KA5 & Kabocha & K13/G9*5/K13 & $\mathrm{BT}, \mathrm{FR}$ & Japan \\
\hline \multicolumn{6}{|c|}{ Male C. moschata } \\
\hline & CB20 & Calabaza & $\mathrm{S}_{6}$ & FR, GC, PQ & Turkey \\
\hline & $\mathrm{CHI} 2$ & Chirimen & $\mathrm{S}_{6}$ & $\mathrm{FR}, \mathrm{PQ}, \mathrm{PV}$ & Japan \\
\hline & FTS5 & Futtsu & $\mathrm{S}_{6}$ & $\mathrm{FR}, \mathrm{GC}, \mathrm{PQ}$ & Japan \\
\hline
\end{tabular}

The seedlings of parents were planted in two rows of $25 \mathrm{~m}$ long with a spacing of $3.0 \mathrm{~m}$ between rows and $2.5 \mathrm{~m}$ within row on $15 \mathrm{May} 2014$ in the BSARI. NPK (15:15:15) fertilizer treatments were applied in three splits, at the rate of $100 \mathrm{~kg} / \mathrm{ha}$ each according soil analyses. Plants were protected against biotic stress with pesticides throughout the growing season. For hybridization, flowers were chosen a day before anthesis. Female flowers were covered with mesh poly bags in the afternoon, so as to prevent pollen contamination. The following morning (06:00-08:00 h), pollens of male flowers were carried onto female flowers, subsequently the flowers were isolated again (Darrudi et al. 2018). At least ten fruits with hybrid seeds were obtained successfully from 21 combinations.

Evaluation of grafted interspecific hybrids and their parents onto watermelon

Seeds of 21 hybrids and their ten parents were sown on 15 March 2015 in seedling plug trays filled with a 1:1:1 (v/v/v) mixture of peat, pearlite and vermiculite. After five days, seeds of watermelon scion 'Crisby $\mathrm{F}_{1} \mathrm{cv}$.' were sown. The seedlings were grown in a controlled greenhouse with $25 / 20^{\circ} \mathrm{C}$ day/night temperatures. Scions were grafted onto the rootstock at the two-cotyledon leaf stage using the splice grafting procedure described by Davis et al. (2008). The experiment was conducted by randomized complete block design in three replications with twenty plants per replicate. Twenty days after grafting, the grafted seedlings were transplanted into $20 \mathrm{~L}$ plastic containers. The climate conditions were as follows: a $16 \mathrm{~h}$ photoperiod, temperature of $25 / 18^{\circ} \mathrm{C}$ (day/night) for 60 days. The grafting success rate (GS) was determined as healthy plant ratio (\%) twenty days after grafting (Karaağaç et al. 2018). Stem diameter (mm) at hypocotyl of rootstocks and the first internode diameter $(\mathrm{mm})$ of the scions were measured by a digital compass after 60 days in thirty plants per grafted combinations (Traka-Mavrona et al. 2000). Hypocotyl thickness ratio (HTR) was calculated from scion/rootstock diameter. The roots of the plants were removed from the containers, washed and dried with paper towel for root system architecture analysis in the same day. An eight-bit grayscale image was obtained by digital scanning at a 400-dpi resolution (Tajima and Kato 2013) by using an image scanner (Epson Expression 10000XL, Epson Inc., USA). WinRHIZO (version 2013, Regent Instruments, QC, Canada) software was used to calculate the root volume (RV, $\left.\mathrm{cm}^{3}\right)$, total root length (RL, $\left.\mathrm{m}\right)$, and average root diameter (ARD, mm) (Fita et al. 2006; Karaağaç 2020; Fig. 2). In this study, hairy root rates (\%) (HRR) were calculated from length per root diameters of less than $0.5 \mathrm{~mm}$ (Suchoff et al. 2017). Subsequently, the roots (RDW), leaves, and shoots (SDW) were dried at $70^{\circ} \mathrm{C}$ for two days and weighed.

The all data recorded on the 21 hybrids and their ten lines were subjected to analysis of variance with the use of JMP 5.0.1 software (SAS Institute, USA) and significant means were compared with the use of LSD test at $P<0.01$ level. The general combining ability variance $(\sigma 2 \mathrm{GCA})$ effects of the lines and the specific combining ability variance ( $\sigma 2 \mathrm{SCA}$ ) effects of the crosses were analyzed by the using of the line $\times$ tester analysis improved by Kempthorne (1957) and modified by Sing and Chaudhary (1985). Narrow-sense heritability $\left(h n^{2}\right)$ was calculated as $[\sigma 2 \mathrm{~A} /(\sigma 2 \mathrm{~A}+\sigma 2 \mathrm{D}+\sigma 2 \mathrm{e})]($ where $\sigma 2 \mathrm{~A}=$ additive genetic variance, $\sigma 2 \mathrm{D}=$ dominance variance, and $\sigma 2 \mathrm{e}=$ error variance) (Falconer 1989). The mid-parent heterosis $(\mathrm{MPH})$ was determined as follows: $\left(\mathrm{F}_{1}-\mathrm{MP}\right) / \mathrm{MP} \times 100$; where, $F_{1}$ is the mean performance of the hybrid; MP is the mid-parent mean (Falconer 1989). The Baker ratio was calculated according to Baker (1978) as follow: $2 \sigma 2 \mathrm{GCA} /(2 \sigma 2 \mathrm{GCA}+\sigma 2 \mathrm{SCA})$. Proportional contribution of females $\left(\mathrm{SS}_{\text {females }} / \mathrm{SS}_{\text {crosses }} \times 100\right)$, males $\left(\mathrm{SS}_{\mathrm{males}} / \mathrm{SS}_{\mathrm{crosses}} \times 100\right)$, and crosses $\left(\mathrm{SS}_{\text {females } \times \text { males }} / \mathrm{SS}_{\text {crosses }} \times 100\right)$ to total variability of each trait was also computed (Sharma et al. 2007).

\section{Results}

The combined analysis of variance (ANOVA) for root volume (RV), root length (RL), root dry weight (RDW), hairy root rates (HRR), average root diameter (ARD), shoot dry weight (SDW), graft success (GS), and hypocotyl thickness ratio (HTR) is presented in Table 2. Results revealed that the effect of genotype was 
significant $(P<0.01)$ for all examined traits. The effect of genotype was sectioned to effects of parent, interspecific cross, female, male, and female $\times$ male. Mean squares of GCA for parents (males and females) were found to be significant for all of examined traits revealing crucial role of additive gene effects except for HRR and GS in females. Mean squares of SCA were also observed to be significant for all of the traits revealing that non-additive gene effects as dominant or epistatic. Such a case indicates the presence of sufficient genetic variability among $C$. maxima, $C$. moschata, and their interspecific hybrids and allows through hybridization followed by breeding and selection in winter squash rootstocks.

Table 2

Analysis of variance for eight traits

\begin{tabular}{|c|c|c|c|c|c|c|c|c|c|}
\hline & & Mean sq & & & & & & & \\
\hline Source & Df & $\mathrm{RV}^{\mathrm{a}}$ & $\mathrm{RL}$ & RDW & HRR & ARD & SDW & GS & HTR \\
\hline Genotypes & 30 & $46.02^{\star \star}$ & $2.91^{* *}$ & $1.43^{* *}$ & $0.02^{* \star}$ & $0.03^{* *}$ & $37.81^{* *}$ & $470.63^{\star \star}$ & $0.04^{* *}$ \\
\hline Parents & 9 & $11.48^{\star \star}$ & $0.49^{\star \star}$ & $0.76^{* *}$ & $0.01^{* *}$ & $0.03^{\star \star}$ & $3.96^{* *}$ & $344.54^{\star \star}$ & $0.08^{* *}$ \\
\hline Interspecific hybrids & 20 & $51.02^{* *}$ & $2.37^{\star \star}$ & $1.39^{* *}$ & $0.01^{* \star}$ & $0.02^{* \star}$ & $30.96^{* *}$ & $361.25^{\star *}$ & $0.02^{* *}$ \\
\hline Females (C. maxima) & 6 & $69.94^{*}$ & $5.01^{*}$ & $1.66^{*}$ & 0.01 & $0.02^{*}$ & $42.03^{*}$ & 498.36 & $0.03^{*}$ \\
\hline Males (C. moschata) & 2 & $199.72^{* *}$ & $3.07^{*}$ & $5.84^{\star *}$ & $0.07^{\star \star}$ & $0.13^{\star *}$ & $100.74^{\star *}$ & $920.24^{*}$ & $0.03^{*}$ \\
\hline Females $\times$ males & 12 & $16.77^{\star \star}$ & $1.10^{\star \star}$ & $0.51^{\star \star}$ & $0.01^{\star *}$ & $0.01^{* \star}$ & $13.79^{\star *}$ & $199.53^{\star \star}$ & $0.01^{* *}$ \\
\hline Error & 60 & 0.15 & 0.01 & 0.00 & 0.00 & 0.00 & 0.13 & 1.57 & 0.00 \\
\hline
\end{tabular}

Mean performance of genotypes

The mean performance of ten parents and 21 interspecific crosses is listed in Table 3. Root volumes (RV) ranged from 5.6 to $17.0 \mathrm{~cm}^{3}$ with a $3-f o l d ~ v a r i a t i o n$. Among parental rootstock combinations, GH12 and GRD17 had the highest RV of $10.2 \mathrm{~cm}^{3}$ and $9.9 \mathrm{~cm}^{3}$ respectively, whereas the lowest (5.6 cm ${ }^{3}$ ) was recorded for B12. Cross rootstock combinations of GRD17 × FTS5 and GH12 × FTS5 provided the highest RV of $17.0 \mathrm{~cm}^{3}$ and $15.0 \mathrm{~cm}^{3}$ respectively. In parents, GRD17 produced the highest root length (RL) value of $4.1 \mathrm{~m}$ followed by female line GLD9 (3.9 m) and male line FTS5 (3.7 m) in descending order. The $\mathrm{RL}$ values of $\mathrm{F}_{1}$ crosses ranged from $6.4 \mathrm{~m}(\mathrm{GH} 12 \times \mathrm{FTS} 5)$ to $3.4 \mathrm{~m}(\mathrm{JA} 2 \times \mathrm{CHI})$ and averaged $4.7 \mathrm{~m}$. Most crosses showed longer root length than their related parents. The parent with the top ranking for root dry weight (RDW) was GRD17 (4.0 g) followed by GH12 (3.3 g) and among the $\mathrm{F}_{1}$ hybrids, GRD17 $\times$ FTS5 $(5.1 \mathrm{~g})$, followed by, GLD9 $\times$ FTS5 $(4.8 \mathrm{~g})$, GH12 $\times$ FTS5 $(4.2 \mathrm{~g})$ and GLD9 $\times$ CHI2 $(4.0 \mathrm{~g})$ the observed best performance for this trait. The best hairy root ratio (HRR) of $0.91,0.89,0.89,0.88$, and 0.87 were displayed in B12 × FTS5, BH5 × FTS5, GRD17 × FTS5, GLD9 × FTS5, and KA5 × FTS5, respectively. Overall, the male parents, FTS5, CHI2, and CB20 exhibited high HRR values of $0.85,0.80$, and 0.74 , respectively. Average root diameters (ARD) ranged from $0.61 \mathrm{~mm}$ for parent GH12 to $0.88 \mathrm{~mm}$ for B12, and $0.55-0.85 \mathrm{~mm}$ for crosses $\mathrm{GH} 12 \times \mathrm{CH} 2$ and GLD9 $\times$ CB20, respectively. Generally, ARD in the $C$. moschata male parents was lower than C. maxima female parents. All crosses, except for GLD9 × CB20, BH5 × CB20, KA5 × CB20, and GRD17 × CB20, had ARD values less than their parents. The cross, GH12 $\times$ FTS5, GLD9 $\times$ FTS5, GRD17 $\times$ FTS5, and the parents, GRD17, FTS5, and GH12 showed the best performance in terms of root structure. The highest shoot dry weight (SDW) was produced by GH12 × FTS5, with $20.3 \mathrm{~g}$, while the lowest SDW was produced by JA2, with $6.8 \mathrm{~g}$. On average, the hybrids onto grafted plants $(14.4 \mathrm{~g})$ produced more shoot than the lines onto grafted plants $(8.6 \mathrm{~g})$. SDW was found to be the trait with the highest difference between parent and hybrids. The hybrid with the highest ranking for graft success (GS) was GLD $9 \times$ FTS 5 ( $99.2 \%)$ followed by GLD $9 \times$ CB20 (98.5\%) and BH5 × FTS5 (97.8\%) and among the parents, FTS5 (90.0\%) followed by CHI2 (87.5\%) displayed the best performance for GS. GS in the $C$. moschata male parents was higher than C. maxima female parents. The lowest grafting performance was determined in $\mathrm{KA} 5$ (55.6\%), GH12 (62.3\%) and KA5 $\times$ CB20 (62.5\%). The greatest hypocotyl thickness ratio (HTR) values belonged to CHI2, FTS5, and CB20 in C. moschata male lines of $1.10,1.06$ and 1.00 respectively. The HTR values of $\mathrm{F}_{1}$ crosses ranged from $0.70(\mathrm{KA} 5 \times \mathrm{CB} 20)$ to $0.96 \mathrm{~m}(\mathrm{GH} 12 \times \mathrm{CB} 20)$ and averaged 0.87 . The best $\mathrm{HTR}$ of $1.00,0.96,0.95$, 0.95 , and 0.94 were observed in $\mathrm{CB} 20, \mathrm{GH} 12 \times \mathrm{CB} 20, \mathrm{GH} 12 \times \mathrm{CHI} 2, \mathrm{BH} 5 \times \mathrm{CHI}$, and GLD $9 \times$ FTS5, respectively. The biggest difference between scion and rootstock hypocotyl thickness was detected in females (C. maxima) with the average of 0.73 . 
Table 3

Mean performance of the parent and their interspecific hybrid rootstocks to grafted watermelon for eight traits

\begin{tabular}{|c|c|c|c|c|c|c|c|c|}
\hline & $\begin{array}{l}\text { RV } \\
\left(\mathrm{cm}^{3}\right)^{a}\end{array}$ & $\begin{array}{l}\mathrm{RL} \\
(\mathrm{m})\end{array}$ & $\begin{array}{l}\text { RDW } \\
\text { (g) }\end{array}$ & HRR (\%) & ARD (mm) & $\operatorname{SDW}(\mathrm{g})$ & GS (\%) & HTR \\
\hline \multicolumn{9}{|c|}{ Interspecific hybrids } \\
\hline $\mathrm{B} 12 \times \mathrm{CB} 20$ & 6.5 & 3.4 & 2.8 & 0.71 & 0.76 & 14.0 & 65.2 & 0.80 \\
\hline $\mathrm{B} 12 \times \mathrm{CHI} 2$ & 8.5 & 4.0 & 2.6 & 0.71 & 0.75 & 9.0 & 70.0 & 0.85 \\
\hline B12 × FTS5 & 12.3 & 4.8 & 3.4 & 0.91 & 0.71 & 13.5 & 82.5 & 0.94 \\
\hline $\mathrm{BH} 5 \times \mathrm{CB} 20$ & 12.9 & 4.9 & 2.8 & 0.71 & 0.82 & 9.1 & 81.8 & 0.84 \\
\hline $\mathrm{BH} 5 \times \mathrm{CHI} 2$ & 8.3 & 5.1 & 3.7 & 0.85 & 0.63 & 12.1 & 85.6 & 0.95 \\
\hline BH5 × FTS5 & 11.0 & 5.4 & 3.9 & 0.89 & 0.66 & 17.0 & 97.8 & 0.92 \\
\hline $\mathrm{GH} 12 \times \mathrm{CB} 20$ & 10.2 & 5.1 & 3.8 & 0.72 & 0.69 & 16.0 & 91.2 & 0.96 \\
\hline $\mathrm{GH} 12 \times \mathrm{CHI} 2$ & 10.5 & 4.9 & 3.7 & 0.81 & 0.55 & 15.3 & 94.5 & 0.95 \\
\hline GH12 × FTS5 & 15.0 & 6.4 & 4.2 & 0.85 & 0.59 & 20.3 & 90.2 & 0.92 \\
\hline GLD9 × CB20 & 9.9 & 5.1 & 3.2 & 0.82 & 0.85 & 14.0 & 98.5 & 0.90 \\
\hline $\mathrm{GLD} 9 \times \mathrm{CHI} 2$ & 10.4 & 5.5 & 4.0 & 0.80 & 0.68 & 15.7 & 80.0 & 0.90 \\
\hline GLD9 × FTS5 & 14.2 & 5.7 & 4.8 & 0.88 & 0.61 & 16.0 & 99.2 & 0.94 \\
\hline GRD17 × CB20 & 12.5 & 3.9 & 3.9 & 0.82 & 0.74 & 8.5 & 68.8 & 0.75 \\
\hline GRD17 × CHI2 & 10.2 & 6.3 & 3.0 & 0.75 & 0.61 & 14.2 & 89.5 & 0.90 \\
\hline GRD17 × FTS5 & 17.0 & 4.8 & 5.1 & 0.89 & 0.61 & 16.9 & 89.5 & 0.86 \\
\hline $\mathrm{JA} 2 \times \mathrm{CB} 20$ & 7.5 & 4.3 & 3.0 & 0.77 & 0.77 & 13.0 & 77.5 & 0.80 \\
\hline $\mathrm{JA} 2 \times \mathrm{CHI} 2$ & 7.7 & 3.4 & 3.4 & 0.74 & 0.70 & 11.5 & 87.5 & 0.85 \\
\hline JA2 × FTS5 & 9.0 & 3.9 & 3.8 & 0.81 & 0.68 & 13.6 & 97.0 & 0.83 \\
\hline $\mathrm{KA} 5 \times \mathrm{CB} 20$ & 7.3 & 3.8 & 2.9 & 0.82 & 0.82 & 8.5 & 62.5 & 0.70 \\
\hline $\mathrm{KA} 5 \times \mathrm{CH} 2$ & 8.1 & 3.7 & 2.7 & 0.81 & 0.59 & 9.1 & 89.6 & 0.78 \\
\hline KA5 × FTS5 & 11.5 & 3.9 & 3.9 & 0.87 & 0.67 & 14.2 & 81.8 & 0.89 \\
\hline \multicolumn{9}{|l|}{ Female parents } \\
\hline B12 & 5.6 & 3.0 & 2.9 & 0.71 & 0.88 & 8.1 & 72.5 & 0.74 \\
\hline BH5 & 8.1 & 2.8 & 2.5 & 0.70 & 0.78 & 8.8 & 65.2 & 0.69 \\
\hline $\mathrm{GH} 12$ & 10.2 & 3.2 & 3.3 & 0.65 & 0.61 & 9.1 & 62.3 & 0.75 \\
\hline GLD9 & 8.5 & 3.9 & 3.2 & 0.68 & 0.83 & 9.9 & 67.8 & 0.80 \\
\hline GRD17 & 9.9 & 4.1 & 4.0 & 0.72 & 0.70 & 10.6 & 71.2 & 0.82 \\
\hline JA2 & 7.1 & 3.5 & 2.1 & 0.62 & 0.87 & 6.8 & 65.2 & 0.69 \\
\hline KA5 & 6.8 & 3.3 & 2.7 & 0.69 & 0.78 & 7.5 & 55.6 & 0.62 \\
\hline \multicolumn{9}{|l|}{ Male parents } \\
\hline CB20 & 7.7 & 3.2 & 2.9 & 0.74 & 0.69 & 8.3 & 73.8 & 1.00 \\
\hline $\mathrm{CHI} 2$ & 7.9 & 3.0 & 3.0 & 0.80 & 0.62 & 8.9 & 87.5 & 1.10 \\
\hline FTS5 & 9.8 & 3.7 & 2.7 & 0.85 & 0.70 & 7.5 & 90.0 & 1.06 \\
\hline CV (\%) & 6.5 & 15.2 & 13.7 & 6.59 & 8.48 & 19.8 & 10.31 & 9.64 \\
\hline $\mathrm{LSD}_{0.01}$ & 1.31 & 0.49 & 0.34 & 0.04 & 0.05 & 1.77 & 6.25 & 0.06 \\
\hline$P<$ & 0.01 & 0.01 & 0.01 & 0.01 & 0.01 & 0.01 & 0.01 & 0.01 \\
\hline
\end{tabular}


The $\sigma 2 \mathrm{GCA}$ was greater than $\sigma 2 \mathrm{SCA}$ for all characters except for GS reflecting the role of additive gene action (Table 4). These traits have had quotient of $\sigma 2$ GCA / $\sigma 2$ SCA greater than one. Main role of non-additive gene effects in the reflection of GS were observed by bigger value of $\sigma 2$ SCA than the $\sigma 2 \mathrm{GCA}$, and quotient of $\sigma 2 \mathrm{GCA} / \sigma 2 \mathrm{SCA}$ being lower than one (Table 4). The present study found $h n^{2}$ of $63.85 \%, 58.98 \%, 55.42 \%, 55.09 \%, 51.36 \%, 49.96 \%, 49.93 \%$, and $40.59 \%$ for ARD, RV, RDW, HRR, RL, HTR, SDW, and GS respectively and averaged $53.60 \%$ (Table 4). The $h n^{2}$ was high for ARD while it was moderate for the other traits. The baker ratio ranged from $58.32-78.64 \%$. The percentage contribution of female, male, female $\times$ line were estimated to each trait and are given in Table 4. Contribution (\%) of male and female were equal for RV and RDW. However, the female for RL, HTR, GS, and SDW were 7.3, 2.2, 1.6, and 1.3 times larger than the male contribution (\%), respectively. Male contributed more to the HRR (55.8\%) and ARD (58.1\%). Contribution of female $\times$ male was slightly lower than that of mean of parents for all traits and averaged $25.3 \%$.

Table 4

Estimates of the genetic variances and heritability for the eight traits in grafted combinations

\begin{tabular}{|c|c|c|c|c|c|c|c|c|}
\hline Genetic parameters & $\mathbf{R V}^{\mathbf{a}}$ & $\mathbf{R L}$ & RDW & HRR & ARD & SDW & GS & HTR \\
\hline$\sigma 2 \mathrm{GCA}$ & 8.18 & 0.36 & 0.22 & 0.002 & 0.004 & 4.56 & 46.16 & 0.0023 \\
\hline$\sigma 2 \mathrm{SCA}$ & 5.54 & 0.33 & 0.17 & 0.002 & 0.002 & 4.44 & 65.99 & 0.0021 \\
\hline o2 GCA / SCA & 1.48 & 1.09 & 1.28 & 1.27 & 1.84 & 1.03 & 0.70 & 1.07 \\
\hline$h n^{2}$ & 58.98 & 51.36 & 55.42 & 55.09 & 63.85 & 49.93 & 40.59 & 49.96 \\
\hline Baker ratio & 74.70 & 68.49 & 71.89 & 71.74 & 78.64 & 67.24 & 58.32 & 68.21 \\
\hline \multicolumn{9}{|c|}{ Proportional contribution to total variance (\%) } \\
\hline Female & 41.1 & 63.5 & 35.9 & 13.5 & 25.2 & 40.7 & 41.4 & 51.6 \\
\hline Male & 39.1 & 8.7 & 42.1 & 55.8 & 58.1 & 32.5 & 25.5 & 23.1 \\
\hline Female $\times$ Male & 19.7 & 27.8 & 22.0 & 30.8 & 16.6 & 26.7 & 33.1 & 25.3 \\
\hline
\end{tabular}

GCA effects

The results related to significant desirable GCA effects and rankings of ten lines for different traits are provided in Table 5. Among the lines BH5, GH12, GLD9, GRD17, and FTS5 had favorable genes for RV due to significant positive GCA effects. The highest positive GCA effects for RL of $0.79,0.75,0.47$ and 0.31 were observed for GH12, GRD17, BH5, and GLD9 in females, respectively. For male parents, only FTS5 had the highest significant positive GCA effects for RL. FTS5, GLD9, GRD17, and GH12 had the highest positive GCA effects of $0.61,0.48,0.45$, and 0.35 for RDW. Female parents, BH5, GLD9, GRD17, KA5 and male parent, FTS5 due to their significant positive GCA effects were found the best combiners for HRR. Desirable GCA effects for ARD should be negative. GCA effect for ARD was revealed that female lines of GH12, GLD9 and male lines of CHI2, FTS5 were the best combiners owing to their significant negative GCA effects. The SDW values of parents ranged from -2.79 to 3.78 and three parents (GH12, GRD17, and FTS5) had positive GCA effects. The order of GCA effects for the GS of the parents was GRD17 > GH12 > FTS5 > BH5 > JA2 > CHI2>GLD9 > CB20 > B12. Due to hypocotyl of female rootstocks wider than scion, those with positive GCA effects in HTR values should be selected. In females, GH12, GRD17, and BH5 had the highest positive GCA effects for HTR of 0.08, 0.05 and 0.04 , respectively, whereas GCA of males was non-significant for this trait. In terms of the total ranking of all traits GH12, GRD17 and FTS5 had a preferred GCA for interspecific rootstock breeding programs. 
Table 5

Estimation of general combining ability (GCA) and its ranking of the parents for eight traits in grafted combinations

\begin{tabular}{|c|c|c|c|c|c|c|c|c|c|c|c|c|c|c|c|c|}
\hline & $\mathbf{R V}^{\mathbf{a}}$ & & RL & & RDW & & HRR & & ARD & & SDW & & GS & & HTR & \\
\hline & GCA & Rank & GCA & Rank & GCA & Rank & GCA & Rank & GCA & Rank & GCA & Rank & GCA & Rank & GCA & Rank \\
\hline \multicolumn{17}{|l|}{ Female } \\
\hline B12 & $-2.10^{\star *}$ & 7 & $-0.61^{\star *}$ & 8 & $-0.60^{\star *}$ & 10 & $-0.03^{\star *}$ & 6 & $0.05^{\star \star}$ & 9 & $-1.23^{\star \star}$ & 8 & $-12.20^{\star \star}$ & 10 & -0.02 & 6 \\
\hline BH5 & $0.36^{\star *}$ & 5 & $0.47^{\star \star}$ & 3 & -0.11 & 5 & $0.01^{\star \star}$ & 4 & $0.01^{\star *}$ & 6 & $-0.68^{\star}$ & 5 & $3.63^{\star \star}$ & 4 & $0.04^{\star \star}$ & 3 \\
\hline $\mathrm{GH} 12$ & $2.11^{\star \star}$ & 3 & $0.79^{\star \star}$ & 1 & $0.35^{\star \star}$ & 4 & $-0.02^{\star \star}$ & 5 & $-0.08^{* \star}$ & 1 & $3.78^{* \star}$ & 1 & $7.20^{\star \star}$ & 2 & $0.08^{\star *}$ & 1 \\
\hline GLD9 & $1.49^{\star \star}$ & 4 & $0.31^{\star \star}$ & 4 & $0.48^{\star \star}$ & 2 & $0.01^{\star \star}$ & 4 & $-0.04^{\star \star}$ & 4 & -0.21 & 4 & -2.17 & 7 & -0.03 & 7 \\
\hline GRD17 & $4.11^{\star \star}$ & 1 & $0.75^{\star \star}$ & 2 & $0.45^{\star \star}$ & 3 & $0.02^{\star \star}$ & 3 & $0.02^{\star \star}$ & 7 & $1.84^{* *}$ & 3 & $7.80^{\star \star}$ & 1 & $0.05^{\star \star}$ & 2 \\
\hline JA2 & $-3.65^{\star *}$ & 10 & $-0.83^{\star *}$ & 9 & $-0.16^{*}$ & 6 & $-0.03^{\star \star}$ & 6 & $0.03^{\star \star}$ & 8 & $-0.71^{*}$ & 6 & $2.56^{\star \star}$ & 5 & $-0.04^{\star *}$ & 8 \\
\hline KA5 & $-2.31^{* *}$ & 9 & $-0.88^{\star *}$ & 10 & $-0.40^{\star *}$ & 9 & $0.03^{\star \star}$ & 2 & 0.00 & 5 & $-2.79^{\star \star}$ & 10 & $-6.80^{\star \star}$ & 8 & $-0.08^{\star \star}$ & 9 \\
\hline \multicolumn{17}{|l|}{ Male } \\
\hline CB20 & $-1.44^{\star *}$ & 6 & $-0.32^{\star *}$ & 7 & $-0.36^{* *}$ & 8 & $-0.05^{\star *}$ & 7 & $0.09^{\star \star}$ & 10 & $-1.53^{\star \star}$ & 9 & $-6.84^{* \star}$ & 9 & -0.02 & 6 \\
\hline $\mathrm{CHI} 2$ & $-2.10^{\star \star}$ & 8 & 0.01 & 6 & $-0.25^{\star}$ & 7 & $-0.02^{\star *}$ & 5 & $-0.05^{\star *}$ & 2 & $-0.98^{*}$ & 7 & 0.47 & 6 & 0.01 & 5 \\
\hline FTS5 & $3.54^{\star \star}$ & 2 & $0.31^{\star \star}$ & 5 & $0.61^{\text {** }}$ & 1 & $0.07^{\star \star}$ & 1 & $-0.04^{\star \star}$ & 3 & $2.51^{\star \star}$ & 2 & $6.37^{\star \star}$ & 3 & 0.01 & 4 \\
\hline
\end{tabular}

SCA effects

Interspecific hybrids exhibited great distinctness in the prominence of SCA effects in both the plus or minus directions (Table 6). Parents of hybrids with significant and desired SCA effects will expedite the development of good rootstocks consequently increasing the possibility of determining strong acting recombinants. Positive SCA effects for the RV were detected in nine crosses, of which BH5 $\times$ CB20, GRD17 $\times$ FTS5, and B12 $\times$ FTS5 ranked in the upper three. On the contrary, BH5 $\times$ FTS5, B12 $\times$ CB20, and GRD17 $\times$ CHI2 showed the highest negative SCA effects for the RV (Table 6). GRD17 $\times$ CHI2, JA2 $\times$ CB20, GH12 $\times$ FTS5, B12 $\times$ FTS5, and KA5 $\times$ CB20 presented a significant and positive SCA effect for the RL. GRD17 $\times$ FTS5, BH5 $\times$ CHI2, GH12 $\times$ CB20, GLD $9 \times \mathrm{CHI}$, GRD17 $\times$ CB20, and JA2 $\times$ CHI2 will experience further assessment for RDW with significantly $(p<0.01)$ high and positive SCA effects of $0.50,0.50,0.29,0.29$, 0.26 , and 0.22 , respectively. For the HRR, the largest SCA effect was found in B12 $\times$ FTS5 (0.06) and BH5 $\times$ CHI2 (0.06) and the lowest was found in BH5 $\times$ CB20 (-0.07). Negative SCA effects for the ARD were determined only in seven of 21 crosses. This result showed that most of the combinations were tend to broader root formation. The SCA effects of the SDW ranged from -3.19 (GRD17 $\times$ CB20) to 3.36 (B12 $\times$ CB20). The highest positive SCA values for GSS belonged to GLD9 $\times$ CB20 (12.78), KA5 × CHI2 (11.16), GRD17 × CHI2 (6.43), and GH12 × CB20 (6.08) while the highest negative ones were recorded for GLD9 $\times$ CHI2 (-13.04), KA5 × CB20 (-8.62), GH12 × FTS5 (-8.14), and GRD17 × CB20 (-6.96). For HTR, significant positive SCA effects were found in KA5 × FTS5, $\mathrm{GH} 12 \times \mathrm{CB} 20, \mathrm{GRD} 17 \times \mathrm{CHI} 2, \mathrm{~B} 12 \times \mathrm{FTS} 5, \mathrm{BH} 5 \times \mathrm{CHI} 2, \mathrm{GLD} 9 \times \mathrm{CB} 20$, and JA2 $\times$ CB20, ranged from 0.02-0.07. Taking all traits into consideration, GRD17 × FTS5, B12 $\times$ FTS5, and JA2 $\times$ CB20 showed up to be the best cross combinations because those combinations had five out of eight traits significant SCA effects. 
Table 6

Estimation of specific combining ability (SCA) and mid-parent heterosis (MPH) (\%) of the interspecific hybrids for eight traits in grafted combinatiol

\begin{tabular}{|c|c|c|c|c|c|c|c|c|c|c|c|c|c|c|c|}
\hline \multirow{2}{*}{$\begin{array}{l}\text { Interspecific } \\
\text { hybrids }\end{array}$} & \multicolumn{2}{|l|}{$\mathbf{R V}^{\mathbf{a}}$} & \multicolumn{2}{|l|}{ RL } & \multicolumn{2}{|l|}{ RDW } & \multicolumn{2}{|l|}{ HRR } & \multicolumn{2}{|l|}{ ARD } & \multirow{2}{*}{$\begin{array}{l}\text { SDW } \\
\text { SCA }\end{array}$} & \multicolumn{2}{|c|}{ GS } & \multirow[b]{2}{*}{ MPH } & \multirow{2}{*}{$\begin{array}{l}\text { HTF } \\
\text { SCA }\end{array}$} \\
\hline & SCA & MPH & SCA & MPH & SCA & MPH & SCA & MPH & SCA & MPH & & MPH & SCA & & \\
\hline $\mathrm{B} 12 \times \mathrm{CB} 20$ & $-2.46^{* *}$ & -2.26 & $-0.30^{\star}$ & 10.74 & $0.19^{\star}$ & -3.39 & $-0.02^{*}$ & -2.07 & $-0.07^{\star \star}$ & -2.99 & $3.36^{* *}$ & 71.25 & -0.52 & -10.87 & $-0.0^{\prime}$ \\
\hline $\mathrm{B} 12 \times \mathrm{CHI} 2$ & $1.20^{\star *}$ & 25.93 & -0.10 & 33.69 & -0.05 & -10.31 & $-0.04^{\star *}$ & -5.96 & $0.05^{\star *}$ & 0.00 & $-2.19^{\star *}$ & 5.88 & $-3.04^{\star \star}$ & -12.50 & $-0.0 ;$ \\
\hline B12 × FTS5 & $1.26^{* *}$ & 59.74 & $0.40^{\star \star}$ & 43.42 & -0.14 & 23.19 & $0.06^{* *}$ & 15.38 & $0.02^{\star *}$ & -9.63 & $-1.18^{\star *}$ & 72.86 & $3.56^{\star *}$ & 1.54 & 0.04 \\
\hline $\mathrm{BH} 5 \times \mathrm{CB} 20$ & $4.69^{\star *}$ & 63.64 & 0.11 & 63.44 & $-0.33^{\star *}$ & 2.84 & $-0.07^{\star \star}$ & $-2.78^{*}$ & $0.03^{\star *}$ & 11.11 & $-2.07^{\star *}$ & 7.11 & 0.24 & 17.70 & $-0.0^{\prime}$ \\
\hline $\mathrm{BH} 5 \times \mathrm{CHI} 2$ & $-1.55^{* *}$ & 3.97 & -0.02 & 77.82 & $0.50^{\text {** }}$ & $34.26^{*}$ & $0.06^{* *}$ & 13.33 & $-0.02^{\star *}$ & -10.00 & 0.31 & 36.31 & $-3.27^{\star *}$ & 12.12 & 0.03 \\
\hline BH5 × FTS5 & $-3.14^{\star *}$ & 23.13 & -0.10 & 65.18 & $-0.17^{*}$ & $51.05^{\star}$ & 0.01 & 14.84 & 0.00 & -11.81 & $1.75^{\star *}$ & 108.34 & $3.03^{\star *}$ & 26.03 & $-0.0:$ \\
\hline $\begin{array}{l}\mathrm{GH} 12 \times \\
\mathrm{CB} 20\end{array}$ & $-1.11^{\star *}$ & 18.83 & -0.05 & 58.14 & $0.29^{* *}$ & 25.25 & $-0.04^{\star *}$ & 0.72 & $-0.01^{*}$ & 6.31 & 0.35 & 84.23 & $6.08^{\star *}$ & 34.02 & 0.06 \\
\hline $\begin{array}{l}\mathrm{GH} 12 \times \\
\mathrm{CH} 22\end{array}$ & 0.00 & 20.92 & $-0.57^{\star *}$ & 58.97 & 0.01 & 16.74 & $0.04^{\star *}$ & 11.72 & $-0.01^{*}$ & -10.48 & $-0.91^{*}$ & 69.70 & $2.06^{\star *}$ & 26.17 & $-0.0^{\circ}$ \\
\hline $\begin{array}{l}\text { GH12 } x \\
\text { FTS5 }\end{array}$ & $1.11^{\star *}$ & 55.71 & $0.62^{\star \star}$ & 85.66 & $-0.29^{\star *}$ & 42.73 & 0.00 & 13.33 & $0.02^{\star *}$ & -10.71 & 0.57 & 143.51 & $-8.14^{\star \star}$ & 18.45 & -0.0 \\
\hline $\begin{array}{l}\text { GLD9 } x \\
\text { CB20 }\end{array}$ & $-0.94^{\star *}$ & 20.98 & -0.04 & 42.99 & $-0.49^{\star \star}$ & 3.62 & $0.02^{*}$ & 12.68 & $0.05^{\star \star}$ & 12.31 & 0.29 & 54.36 & $12.78^{\star \star}$ & 39.12 & 0.03 \\
\hline $\begin{array}{l}\text { GLD9 } x \\
\text { CHI2 }\end{array}$ & 0.41 & 25.07 & 0.05 & 60.70 & $0.29^{\star *}$ & 29.65 & -0.01 & 8.11 & $0.01^{*}$ & -6.45 & $1.48^{* *}$ & 67.54 & $-13.04^{\star \star}$ & 3.03 & -0.0 \\
\hline $\begin{array}{l}\text { GLD9 } x \\
\text { FTS5 }\end{array}$ & $0.53^{*}$ & 53.79 & -0.01 & 51.94 & $0.21^{\star *}$ & 64.13 & -0.01 & 15.03 & $-0.06^{\star *}$ & -20.61 & $-1.77^{\star *}$ & 83.57 & 0.26 & 25.73 & $-0.0^{\circ}$ \\
\hline $\begin{array}{l}\text { GRD17 x } \\
\text { CB20 }\end{array}$ & 0.34 & 45.63 & $-0.77^{\star *}$ & 7.44 & $0.26^{\star *}$ & 15.13 & $0.03^{*}$ & 9.59 & 0.00 & 5.88 & $-3.19^{\star *}$ & -9.94 & $-6.96^{\star *}$ & -5.10 & $-0.0<$ \\
\hline $\begin{array}{l}\text { GRD17 x } \\
\text { CHI2 }\end{array}$ & $-2.45^{\star *}$ & 17.47 & $1.25^{\star \star}$ & 78.63 & $-0.76^{\star *}$ & -13.65 & $-0.04^{\star *}$ & -1.32 & 0.00 & -7.96 & $2.03^{* \star}$ & 46.35 & $6.43^{\star \star}$ & 12.79 & 0.05 \\
\hline $\begin{array}{l}\text { GRD17 x } \\
\text { FTS5 }\end{array}$ & $2.11^{\star *}$ & 76.47 & $-0.47^{\star *}$ & 25.30 & $0.50^{\star *}$ & 55.12 & 0.01 & 13.38 & 0.00 & -13.33 & $1.17^{* \star}$ & 86.62 & 0.53 & 11.04 & $-0.0^{\circ}$ \\
\hline $\mathrm{JA} 2 \times \mathrm{CB} 20$ & $0.59^{*}$ & 3.93 & $0.76^{\star \star}$ & 28.43 & 0.00 & 21.62 & $0.05^{\star *}$ & 13.56 & $-0.04^{\star *}$ & -0.75 & $1.84^{\star \star}$ & 72.99 & -2.99 & 11.51 & 0.02 \\
\hline $\mathrm{JA} 2 \times \mathrm{CHI} 2$ & $1.55^{\star \star}$ & 5.24 & $-0.50^{\star *}$ & 4.88 & $0.22^{\star *}$ & 30.99 & -0.01 & 4.23 & $0.03^{\star \star}$ & -5.51 & -0.21 & 46.68 & -0.30 & 14.60 & 0.01 \\
\hline JA2 × FTS5 & $-2.14^{\star *}$ & 8.87 & $-0.26^{*}$ & 9.40 & $-0.22^{\star *}$ & 58.49 & $-0.04^{\star \star}$ & 8.84 & $0.01^{*}$ & -13.43 & $-1.64^{* *}$ & 89.65 & $3.30^{\star *}$ & 25.00 & -0.0 \\
\hline $\mathrm{KA} 5 \times \mathrm{CB} 20$ & $-1.12^{\star *}$ & -6.85 & $0.29^{*}$ & 16.48 & 0.08 & 4.24 & $0.03^{*}$ & 14.55 & $0.04^{\star *}$ & 11.11 & -0.58 & 7.80 & $-8.62^{\star \star}$ & -3.40 & -0.0 \\
\hline $\mathrm{KA} 5 \times \mathrm{CH} 2$ & $0.84^{\star *}$ & 3.00 & -0.12 & 19.03 & $-0.19^{*}$ & -4.28 & 0.00 & 8.72 & $-0.06^{\star \star}$ & -16.67 & -0.51 & 11.08 & $11.16^{\star \star}$ & 25.23 & $-0.0^{\prime}$ \\
\hline KA5 × FTS5 & 0.27 & 30.19 & -0.17 & 13.92 & 0.12 & 46.21 & $-0.03^{*}$ & 12.99 & $0.02^{\star \star}$ & -10.24 & $1.09^{* \star}$ & 88.96 & -2.54 & 12.36 & 0.07 \\
\hline
\end{tabular}

a: See Table 2 for trait abbreviations ${ }^{*}{ }^{* *}$ Significance at $P<0.05$ and $P<0.01$, respectively

Heterosis

MPH of the interspecific hybrids varied considerably (Table 6). In the present study, the cross GRD17 $\times$ FTS5, BH5 $\times$ CB20, and GH12 $\times$ FTS5 revealed high positive values of MPH for the RV. MPH of RL ranged from $4.88 \%(\mathrm{JA2} \times \mathrm{CHI} 2)$ to $85.66 \%(\mathrm{GH} 12 \times \mathrm{FTS} 5)$ with a 18-fold variation. MPH was mostly positive for RDW and the best hybrid combination was GLD9 $\times$ FTS5 followed by JA2 × FTS5 and GRD17 × FTS5. The most positive MPH for HRR was shown by B12 $\times$ FTS5 (15.38\%), followed by GLD9 $\times$ FTS5 (15.03\%). Negative heterosis for ARD is desirable. Crosses showing negative heterosis for this trait were GLD $9 \times$ FTS5, KA5 $\times$ CHI2, and GRD17 $\times$ FTS5. Seven crosses displayed positive MPH of up to $80 \%$ for SDW. Hybrids such as GH12 $\times$ FTS5 and BH5 $\times$ FTS5 showed positive MPH of more than $100 \%$ for this trait. For GS, GLD9 $\times$ CB20 (39.12\%), GH12 × CB20 (34.02\%), and BH5 $\times$ FTS5 (26.03\%) showed highest heterosis values. MPH of HTR values of interspecific crosses ranged from - 17.58-9.71\%. Only eight crosses expressed heterosis over the mid-parent (Table 6).

\section{Discussion}

The interspecific hybrid C. maxima $\times$ C. moschata combinations have been utilized as a favorable source of rootstocks with most of the currently used trading rootstocks coming from breeding work performed. New compatible combinations of C. maxima $\times$ C. moschata are being identified by screening alternative germplasm collections of these species (Karaağaç and Balkaya 2013; Uretsky and Loy 2017). Given the complex nature of the genetic of root architecture, knowledge of genetic components of rooting would be essential for the optimal design of tools and strategies aimed at improving root vigor in rootstock 
cultivars (Karaağaç 2020). Combination ability test is a helpful technique that can be used for parent selection in hybrid variety breeding. Notwithstanding the fact that, no study on combining ability of interspecific Cucurbita rootstock has been reported to our knowledge. Although these rootstock varieties have been developed, it has been reported that these varieties have very similar genetic structure (Kong et al. 2014; Edelstein et al. 2017). Because of the lack of interspecific compatibility in the gene pool and the low selection efficiency in root characteristics, the number of interspecific hybrid rootstock registered much less than the intraspecific hybrid varieties.

In this study, eight important traits for rootstock breeding RV, RL, RDW, HRR, ARD, SDW, GS, and HTR were investigated. Ten lines with unlike feature were used to get the appropriate genetic variance for root and hypocotyl structure. A magnificent amount of genetic variation was identified from the variance analysis. Combined ANOVA statistics show that there was a significant difference for measured traits. The means of $C$. maxima $\times$ C. moschata interspecific hybrids for all root traits expect for ARD were higher than the average values of their parents. The lower ARD in some $C$. maxima $\times$ C. moschata rootstocks were similar to the findings of Bertucci et al. (2018). In general, more intensively branched rootstock system can intake the scion's needs from a soil more effectively than a weak root system (Gregory 2006). And as well, strong rootstocks must be in good compatibility with the scions. Shoot biomass and grafted success rate of the hybrids have increased as compared to the parents, 1.5 times and approximately $20 \%$, respectively. In previous studies, it was reported that interspecific hybrids rootstocks performed better than C. maxima and C. moschata rootstocks in terms of root vigor and grafting success (Davis et al. 2008; King et al. 2010; Thompson et al. 2017). However, Edelstein et al. (2017) found the same rooting capacity values between interspecific hybrid rootstocks and their parents in grafted melon. This may be due to the limited parent variation, the heterotic effect may not have occurred.

GCA effect is the most important indicator designating the average potential value of a parent used in a series of hybrid combinations and is based on additive genes, whereas SCA effect is the expression of the variability of the GCA effect of this parent used in different hybrid combinations and is associated with non-additive genes (Musembi et al. 2015). In this current study, the significant GCA and SCA effects on root traits imply that both additive and dominant gene effects are included in C. maxima $\times$ C. moschata rootstocks. Sharma et al. (1991) reported that high quotients of GCA / SCA mean that the additive gene action causes a larger contribution to the expression of specific characters than non-additive gene action. This study revealed that the additive gene action had important effects in expression of all traits except for GS. The precedence of additive genetic variation for these characters indicates that the parent could be selected based on root and shoot traits of GCA values. The supremacy of additive genetic variance for one trait also means that, apart from hybrid variety breeding, the chance exists for genetic advance by accumulating proper genes via selection (Feyzian et al. 2009). This result complies with the findings of the other authors who determined that GCA was more functional than SCA in generation performance for root vigor in pea (Saleh and Gritton 1988), melon (Fita et al. 2006), sweet potato (Kagimbo et al. 2019), and bean (Cerutti et al. 2020). On the contrary, both non-additive and additive gene actions were equitably significant in the control of GS, as the ratio was between 0.50 and 1.0 (Pandiarana et al. 2015). The $h n^{2}$ is proportion of additive genetic variance to phenotypic variance (Nyquist and Baker 1991) and graded as low (below 30\%), medium (30\%-60\%), and high (above 60\%) (Robinson et al. 1949). Accordingly, moderate heritability was exhibited for all of the traits except for ARD and for it, high heritability (63.85\%) was recorded. These findings indicated that the selection for these characters can be applied in the early generations of selection breeding programs. However, the Baker ratios (Baker 1978) were lower than $80 \%$ indicating the moderate contribution of the non-additive gene effects in the genetic control of traits. These results show that dominance effects should not be neglected in the determination of the measured traits of the rootstocks (Acquaah 2012). Rootstocks with a strong root system and plentiful hairy roots have an advantage in their capacity to rapidly retrieve from the influence of biotic stress (Katuuramu et al. 2020). Contribution of female parent (C. maxima) was slightly greater than that of males and hybrids for RL and HTR traits. The hypocotyl thickness values of the female parents were found to be wider than desired. Therefore, female parents with narrow hypocotyls should be selected for rootstock breeding. Given the assumed importance of HRR and ARD in rootstocks, male parent effects were expected to be more important than female parent effects in experimental interspecific hybrids. All sources of variation contributed evenly for the other traits. This finding suggest that female parents ( $C$. maxima) for root vigor and hypocotyl properties and male parents $(C$. moschata) for hairy root are more important and should be taken into consideration in selection of rootstock parent.

Interspecific rootstocks play an important role in accelerating the breeding programs due to the high additive gene effect of parents with the desired direction and important GCA effect (Su et al. 2017). Consequently, FTS5 genotype showed good effects for nearly all characters and could therefore be accepted as a superior male parent in interspecific rootstock breeding. Female parent, GLD9 genotype had the most important GCA effects for all the root traits in the desired direction but did not stand out in terms of other plant characteristics. This was followed by GH12 with four root characters (RV, RL, RDW, and ARD) and GRD17 with four root characters (RV, RL, RDW, and HRR) in female parents. Same female lines, GH12 and GRD17 had favorable genes for shoot, hypocotyl and grafting success rate due to significant positive GCA effects. In this study, male FTS5 and female GH12 and GRD17 lines were the best parents with higher general combining ability. Specific combining ability is useful to determine different hybrids with desired characters (Rukundo et al. 2017). Similarly, interspecific hybrids also stood out diverse (i.e., plus or minus) SCA effects for these traits. In present study, the most appropriate cross combinations, GRD17 $\times$ FTS5, B12 $\times$ FTS5, and BH5 $\times$ CHI2 showed significant SCA effects for root vigor-related traits. These hybrids can be noted in rootstock breeding programs for improved root traits. Three hybrids, namely GH12 × CB20, GLD9 $\times$ CB20, and B12 $\times$ FTS5 with high grafting compatibility-related traits are recommended to further improve interspecific rootstock breeding. The outstanding of crosses will depend on mean performance of hybrids and over mid-parent heterosis (Shashikumar et al. 2011). About $60 \%$ of the crosses exceeded the parental values for the desired mean values of all traits. The highest heterosis among traits was determined in shoot length of the scion with an average of $60 \%$. Similarly, C. maxima $\times$ C. moschata interspecific hybrids were described as highly vigorous cultivars (Uretsky and Loy 2017). Although the GCA effect is more important than the SCA effect for all traits, the high MPH values show that the dominant gene effect is also important in interspecific rootstock selection. It was reported that in such cases, heterosis and combining ability should be evaluated together (Kenga et al. 2004). For example, GRD17 × FTS5 and its parents had desired direction and significant SCA-GCA and high MPH, in terms of root and shoot vigor.

\section{Conclusion}


This study presented the first report on the heritability, combining ability, and heterosis for root system architecture and graft-related traits in $C$. maxima $\times$. moschata interspecific rootstocks and their parents. Both non-additive and additive gene actions were specified to be substantial in the expression of all traits for which lines and hybrids noted the best combination ability effects in the desired directions. Besides, additive gene action was the preponderant type of gene action controlling all traits except for grafting success. Significant GCA effects and moderate or high $h n^{2}$ indicated that selection-based strategies that are highly responsive to additive effects increase genetic improvement of suitable root and shoot traits in early generations $\left(F_{3}\right)$ in rootstock breeding of winter squashes that can be interspecific cross ability with each other. Since the grafting success rate was a higher SCA, selection should be made of interspecific hybrids for this criterion. The same case is also valid in terms of hairy root capacity in $C$. moschata and root volume and hypocotyl thickness in $C$. maxima genotypes. Present findings revealed that the futtsu type $C$. moschata as male and hubbard or delicious types $C$. maxima as female were good combiners for RSA and graft-related traits. In addition, selection efficiency is expected to be the best in the cross combinations including lines having high GCA effects and the cross combinations which displayed high SCA effects can best be exploited in heterosis rootstock breeding.

\section{Declarations}

Acknowledgements This research was supported by Ondokuz Mayis University and Republic of Turkey Ministry of Agriculture and Forestry. The author is grateful to Prof. Dr. Ahmet Balkaya (Ondokuz Mayis University of Samsun, Turkey) for helpful discussions during preparation of the manuscript.

\section{Declarations}

Funding This research was partly financed by the project PYO.ZRT.1901.09.015 from the Ondokuz Mayis University.

Conflict of interest The author declares no conflict of interest.

\section{References}

Acquaah G (2012) Principles of plant genetics and breeding, $2^{\text {nd }}$ edn. John Wiley \& Sons, West Sussex, UK.

https://doi.org/10.1002/9781118313718

Anido FL, Cravero V, Asprelli P, Firpo T, García SM, Cointry E (2004) Heterotic patterns in hybrids involving cultivar-groups of summer squash, Cucurbita pepo L. Euphytica 135(3): 355-360. https://doi.org/10.1023/B:EUPH.0000013373.91446.f3

Ara N, Yang J, Hu Z, Zhang M (2013) Determination of heat tolerance of interspecific (Cucurbita maximax Cucurbita moschata) inbred line of squash 'Maxchata' and its parents through photosynthetic response. J. Agric. Sci. 19(3): 188-197. https://doi.org/10.1501/Tarimbil_0000001244

Baker RJ (1978) Issues in diallel analysis. Crop Sci. 18: 533-536. https://doi.org/10.2135/cropsci1978.0011183X001800040001x

Bertucci MB, Suchoff DH, Jennings KM, Monks DW, Gunter CC, Schultheis JR, Louws FJ (2018) Comparison of root system morphology of cucurbit rootstocks for use in watermelon grafting. Horttechnology 28(5): 629-636. https://doi.org/10.21273/HORTTECH04098-18

Bie Z, Nawaz MA, Huang Y, Lee JM, Colla G (2017) Introduction of vegetable grafting. In: Colla G, Pérez-Alfocea F, Schwarz D (eds.) Vegetable grafting: principles and practices, CABI Publishing, Wallingford, UK, pp 1-21

Cerutti PH, Grigolo S, Melo RC, Fioreze ACCL, Guidolin AF, Coimbra JLM (2020) Combining ability between common bean gene groups for root distribution trait. Ciênc. Agrotec. 44: e011520. https://doi.org/10.1590/1413-7054202044011520

Darrudi R, Nazeri V, Soltani F, Shokrpour M, Ercolano MR (2018) Evaluation of combining ability in Cucurbita pepo L. and Cucurbita moschata Duchesne accessions for fruit and seed quantitative traits. J Appl Res Med Aromat Plants 9: 70-77. https://doi.org/10.1016/j.jarmap.2018.02.006

Davis AR, Perkins-Veazie P, Sakata Y, Lopez-Galarza S, Maroto JV, Lee SG, Huh YC, Sun Z, Miguel A, King SR, Cohen R, Lee JM (2008) Cucurbit grafting. CRC Crit Rev. Plant Sci. 27(1): 50-74. https://doi.org/10.1080/07352680802053940

Dehdar B, Amiri S, Panahi B, Mohammadi R (2020) Combining ability analysis of tuber yield and related traits in potatoes. Genetika 52(1), $215-228$. https://doi.org/10.2298/GENSR2001215D

Devi P, Lukas S, Miles C (2020) Advances in watermelon grafting to increase efficiency and automation. Horticulturae 6(4): 1-13.

https://doi.org/10.3390/horticulturae6040088

Edelstein M, Cohen R, Gur A, Elkabetz M, Pivonia S, Grosch R, Forster P, Schwarz D (2017) Performance of interspecific Cucurbita rootstocks compared to their parental lines. Sci. Hortic. 216: 45-50. https://doi.org/10.1016/j.scienta.2016.12.031

Falconer DS (1989) Introduction to quantitative genetics. $3^{\text {rd }}$ edn. Longman Scientific \& Technical, Essex, England and John Wiley \& Sons, Inc. New York, USA

Fellahi ZEA, Hannachi A, Bouzerzour H, Boutekrabt A (2013) Linex tester mating design analysis for grain yield and yield related traits in bread wheat (Triticum aestivum L.). Int. J. Agron. 2013: 1-9. https://doi.org/10.1155/2013/201851 
Feyzian E, Dehghani H, Rezai AM, Javaran MJ (2009) Diallel cross analysis for maturity and yield-related traits in melon (Cucumis melo L.). Euphytica 168(2): 215-223. https://doi.org/10.1007/s10681-009-9904-9

Fita A, Picó B, Nuez F (2006) Implications of the genetics of root structure in melon breeding. J. Am. Soc. Hortic. Sci, 131(3), $372-379$. https://doi.org/10.21273/JASHS.131.3.372

Gregory PJ (2006) Plant roots: growth, activity and interaction with soils. Blackwell Publishing, Oxford, UK

Hassell RL, Memmott F, Liere DG (2008) Grafting methods for watermelon production. HortScience 43(6): 1677-1679. https://doi.org/10.21273/HORTSCl.43.6.1677

Hayase H (1950) Cucurbita-crosses, I. The pollen tube growth in interspecific crosses. J. Jour. Genetic 25: 181-190

Kagimbo F, Shimelis H, Sibiya J (2019) Combining ability, gene action and heritability of weevil resistance, storage root yield and yield related-traits in sweetpotato. Euphytica 215(13): 1-17. https://doi.org/10.1007/s10681-019-2338-0

Kanagarasu S, Nallathambi G, Ganesan KN (2010) Combining ability analysis for yield and its component traits in maize (Zea mays L.). Electron. J. Plant Breed. 1(4): 915-920

Kanda T (1984) Squash. In: Shinohara S (ed) Vegetable Seed Production Technology of Japan Elucidated with Respective Variety Development Histories, Particulars Shinohara's Authorized Agr. Consult. Engineer Office. Nishiooi, Japan. Vol I, pp 395-426

Karaağaç O (2013) Determination of rootstock potential of winter squash (C. maxima Duchesne) and pumpkin (C. moschata Duchesne) genotypes selected from Black Sea Region for watermelon. Doctoral dissertation, Ondokuz Mayis University, Samsun, Turkey, p 256 (in Turkish)

Karaağaç O, Balkaya A (2013) Interspecific hybridization and hybrid seed yield of winter squash (Cucurbita maxima Duch.) and pumpkin (Cucurbita moschata Duch.) lines for rootstock breeding. Sci. Hortic. 149: 9-12. https://doi.org/10.1016/j.scienta.2012.10.021

Karaağaç O, Balkaya A, Göçmen M, Şimşek I, Kandemir D (2018) Use of phenotypic selection and hypocotyl properties as predictive selection criteria in pumpkin (Cucurbita moschata Duch.) rootstock lines used for grafted cucumber (Cucumis sativus L.) seedling cultivation. Turk J Agric For. 42 (2): $124-135$. https://doi.org/10.3906/tar-1709-52

Karaağaç O (2020) Hybrid Cucurbita rootstocks improve root architecture, yield, quality, and antioxidant defense systems of cucumber (Cucumis sativus) under low temperature conditions. Int J Agric Biol. 23(3): 613-622. https://doi.org/10.17957/IJAB/15.1331

Katuuramu DN, Wechter WP, Washington ML, Horry M, Cutulle MA, Jarret RL, Levi A (2020) Phenotypic diversity for root traits and identification of superior germplasm for root breeding in watermelon. HortScience 55(8): 1272-1279. https://doi.org/10.21273/HORTSCI15093-20

Kempthorne $O$ (1957) An introduction to genetic statistics. John Wiley \& Sons, New York, USA

Kenga R, Alabi SO, Gupta SC (2004) Combining ability studies in tropical sorghum (Sorghum bicolor(L.) Moench). Field Crops Res. 88(2-3): 251-260. https://doi.org/10.1016/j.fcr.2004.01.002

King SR, Davis AR, Zhang X, Crosby K (2010) Genetics, breeding and selection of rootstocks for Solanaceae and Cucurbitaceae. Sci. Hort. 127 : $106-111$. https://doi.org/10.1016/j.scienta.2010.08.001

Kong Q, Chen J, Liu Y, Ma Y, Liu P, Wu S, Huang Y, Bie Z (2014) Genetic diversity of Cucurbita rootstock germplasm as assessed using simple sequence repeat markers. Sci. Hort. 175: 150-155. https://doi.org/10.1016/j.scienta.2014.06.009

Korakot N, Yang J, Zhang M, Ye F, Lin Y (2010) A novel inbred squash line developed from interspecific crosses between Cucurbita maxima and Cucurbita moschata. In: Thies J, Levi A, Kousik S (eds.) Proceeding Cucurbitaceae 2010. 14-18 November, Charleston, South Carolina. USA. pp 129-131

Korzeniewska A, Niemirowicz-Szczytt K (1993) Combining ability and heterosis effect in winter squash (Cucurbita maxima Duch.). Genet. Pol. 34(3): 259-272

Musembi KB, Githiri SM, Yencho GC, Sibiya J (2015) Combining ability and heterosis for yield and drought tolerance traits under managed drought stress in sweetpotato. Euphytica 201(3): 423-440. https://doi.org/10.1007/s10681-014-1230-1

Pandiarana N, Chattopadhyay A, Seth T, Shende VD, Dutta S, Hazra P (2015) Heterobeltiosis, potence ratio and genetic control of processing quality and disease severity traits in tomato. N.Z.J. Crop Hortic. Sci. 43(4): 282-293. https://doi.org/10.1080/01140671.2015.1083039

Picó B, Thompson AJ, Gisbert C, Yetișir H, Bebeli PJ, Colla G (2017) Genetic resources for rootstock breeding. In: Colla G, Pérez-Alfocea F, Schwarz D (eds.) Vegetable grafting: principles and practices. CABI Publishing, Wallingford, UK, pp 22-69

Robinson HF, Comstock RE, Harvey PH (1949) Estimates of heritability and the degree of dominance in corn. J. Agron. 41(8): $353-359$. https://doi.org/10.2134/agronj1949.00021962004100080005x

Rukundo P, Shimelis H, Laing M, Gahakwa D (2017) Combining ability, maternal effects, and heritability of drought tolerance, yield and yield components in sweetpotato. Front. Plant Sci. 7(1981): 1-14. https://doi.org/10.3389/fpls.2016.01981

Page 11/14 
Saleh GB, Gritton ET (1988) Genetic control of root weight, root volume and root to shoot weight ratio in peas. Pertanika 11(2): 165-173

Sharma HC, Dhillon MK, Pampapathy G, Reddy BVS (2007) Inheritance of resistance to spotted stem borer, Chilo partellus, in sorghum, Sorghum bicolor. Euphytica 156(1): 117-128. https://doi.org/10.1007/s10681-007-9358-x

Sharma RC, Smith EL, McNew RW (1991) Combining ability analysis for harvest index in winter wheat. Euphytica 55(3): $229-234$.

https://doi.org/10.1007/BF00021243

Shashikumar KT, Pitchaimuthu M, Kumar DP, Rawal RD (2011) Heterosis and combining ability for resistance to powdery mildew in adult melon plants. Plant Breed.130(3): 383-387. https://doi.org/10.1111/j.1439-0523.2010.01798.x

Sheshshayee MS, Abou-Kheir E, Rohini S, Srivastava N, Mohanraju B, Nataraja KN, Prasad TG, Dayakumar M (2011) Phenotyping for root traits and their improvement through biotechnological approaches for sustaining crop productivity. In: Costa de Oliveira A, Varshney R (eds.) Root genomics. Springer, Berlin, Germany, pp 205-232

Singh RK, Chaudhary BD (1985) Biometrical methods in quantitative genetic analysis. Kalyani Publishers, New Delhi, India

Su J, Zhang F, Yang X, Feng Y, Yang X, Wu Y, Guan Z, Fang F, Chen F (2017) Combining ability, heterosis, genetic distance and their intercorrelations for waterlogging tolerance traits in chrysanthemum. Euphytica 213(42): 1-15. https://doi.org/10.1007/s10681-017-1837-0

Suchoff DH, Gunter CC, Louws FJ (2017) Comparative analysis of root system morphology in tomato rootstocks. HortTech. $27(3)$ : $319-324$.

https://doi.org/10.21273/HORTTECH03654-17

Tajima R, Kato Y (2013) A quick method to estimate root length in each diameter class using freeware image. J. Plant Prod. Sci. 16(1): 9-11.

https://doi.org/10.1626/pps.16.9

Tamilselvi NA, Jansirani P, Pugalendhi L (2015) Estimation of heterosis and combining ability for earliness and yield characters in pumpkin (Cucurbita moschata Duch. Ex. Poir). Afr. J. Agric. Res. 10(16): 1904-1912. https://doi.org/10.5897/AJAR2014.9099

Thompson AJ, Picó B, Yetișir H, Cohen R, Bebeli PJ (2017) Rootstock breeding: current practices and future technologies. In: Colla G, Pérez-Alfocea F, Schwarz $\mathrm{D}$ (eds.) Vegetable grafting: principles and practices. CABI Publishing, Wallingford, UK, pp 70-93

Traka-Mavrona E, Koutsika-Sotiriou M, Pritsa T (2000) Response of squash (Cucurbita spp.) as rootstock for melon (Cucumis melo L.). Sci. Hort. 83(3-4): 353362. https://doi.org/10.1016/S0304-4238(99)00088-6

Uretsky J, Loy JB (2017): Evaluation of morphological traits associated with productivity in $\mathrm{F}_{1}$ interspecific (Cucurbita maxima Duch. x C. moschata Duch.) hybrid processing squash. Hortscience 52(9): 1156-1163. https://doi.org/10.21273/HORTSCI12018-17

Wachsman G, Sparks EE, Benfey PN (2015) Genes and networks regulating root anatomy and architecture. New Phytol. 208(1): 26-38.

https://doi.org/10.1111/nph.13469

Whitaker TW (1933) Cytological and phylogenetic studies in the Cucurbitaceae. Bot. Gaz. 94(4): 780-790

Ye H, Roorkiwal M, Valliyodan B, Zhou L, Chen P, Varshney RK, Nguyen HT (2018) Genetic diversity of root system architecture in response to drought stress in grain legumes. J. Exp. Bot. 69(13): 3267-3277. https://doi.org/10.1093/jxb/ery082

Zhang QI, Yu E, Medina A (2012) Development of advanced interspecific-bridge lines among Cucurbita pepo, C. maxima, and C. moschata. HortScience 47(4): 452-458. https://doi.org/10.21273/HORTSCl.47.4.452

\section{Figures}




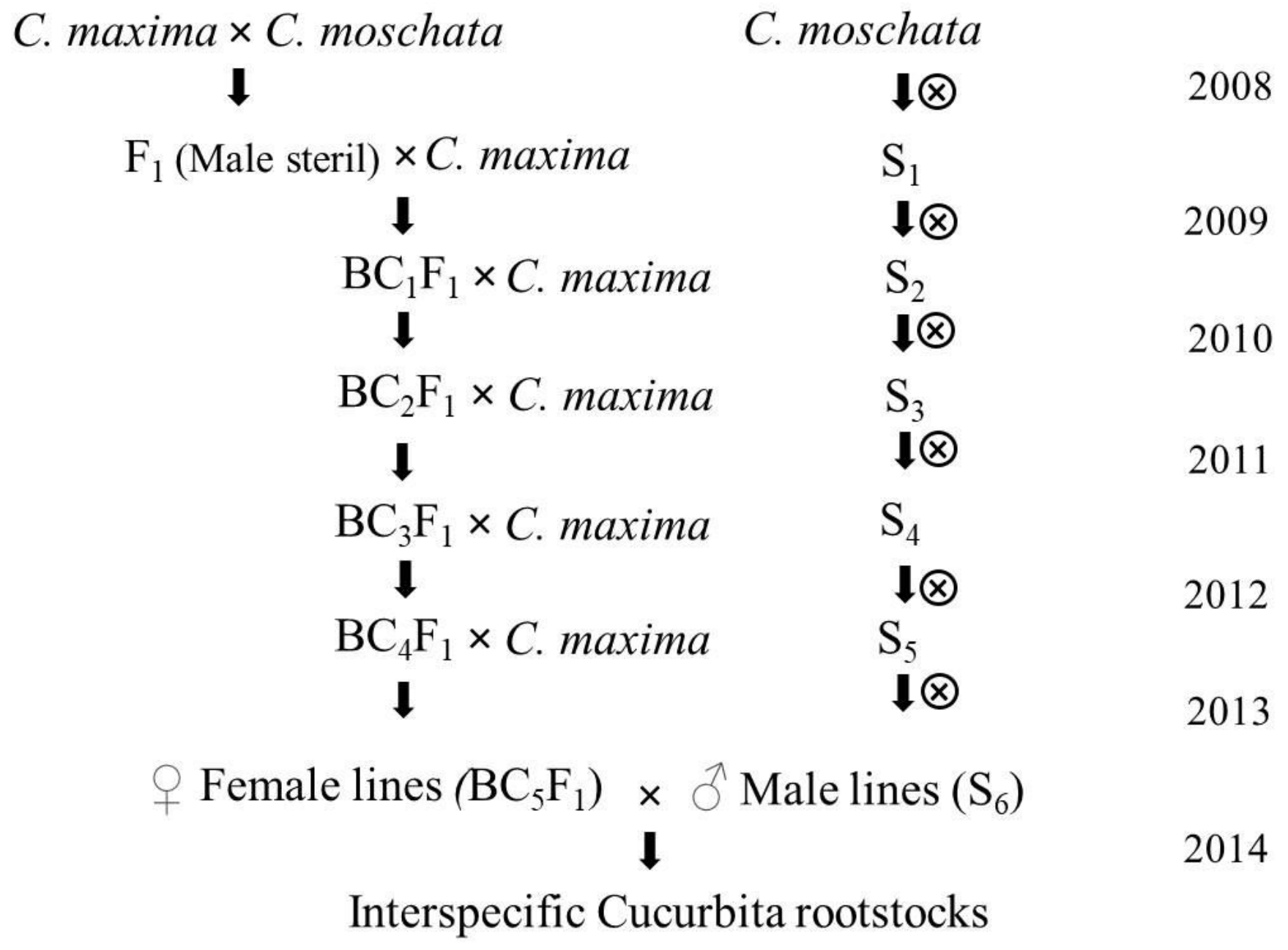

Figure 1

These lines backcrossed with bridge lines close to C. moschata and selfed five times with the use of modified procedure of Korakot et al. (2010) for five years between 2008 and 2014 


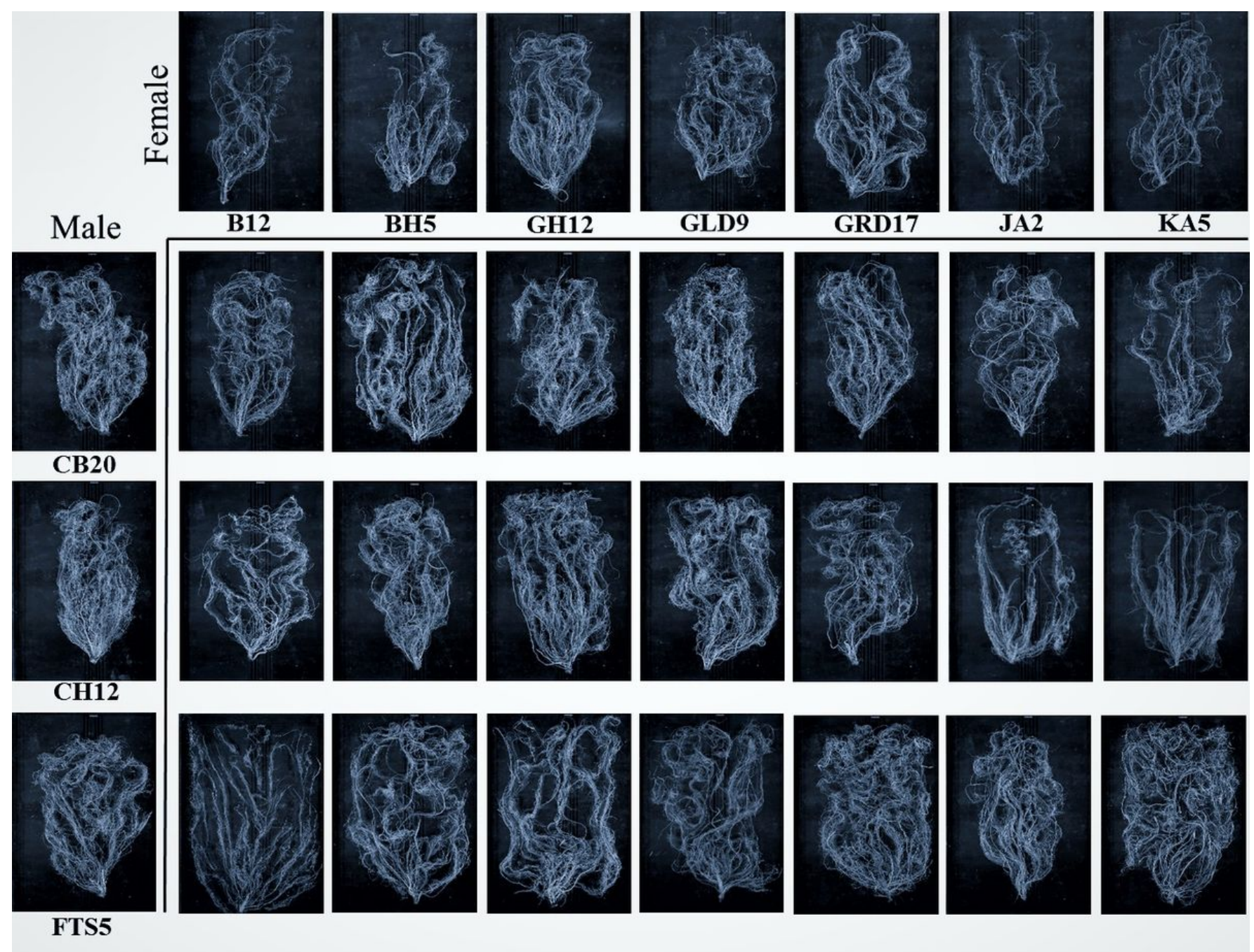

Figure 2

WinRHIZO (version 2013, Regent Instruments, QC, Canada) software was used to calculate the root volume (RV, cm3), total root length (RL, m), and average root diameter (ARD, mm) (Fita et al. 2006; Karaağaç 2020;). 